\title{
Educational Values of Indonesian Character Education in Sharia Maqasid Perspective
}

\author{
Duski Ibrahim* \\ Raden Fatah State University \\ Palembang, Indonesia \\ *duski_uin@radenfatah.ac.id
}

\begin{abstract}
To improve the quality of education in various aspects, the Indonesia has formulated 18 significant character values that must be guided in the implementation of the teaching and learning process. Those values are actually in accordance with Islamic teachings, especially with the approach or in the perspective of maqasid sharia, whose essence is to realize the merit of humans, both in this world and in the hereafter, by maintaining the five principles known as al-kulliyat al-Khams, namely maintaining religion, soul, reason, descent including honor, and maintaining property. This study aims to analyze the existence of character education values which are used as guidelines in the implementation of education in Indonesia. The study data are the formulation of character education values that have been formalized by Indonesian government in the implementation of education in various fields, then the interpretations that have been carried out by educational experts, which are collected through literature studies. The data are analyzed through a descriptive qualitative approach. After conducting an analysis based on the benchmarks of the maqasid of sharia, the results of the study show that the values of the character of the Indonesian education are in line with the principles or rules of maqasid sharia. Therefore, the values of the character education of the Indonesia can be maintained and Indonesian people can be creative in advancing education in Indonesia in a pluralistic society.
\end{abstract}

Keywords-the values of character education, sharia maqasid

\section{INTRODUCTION}

Indonesian society is very diverse, consisting of various ethnic groups, religions, languages, and cultures. Therefore, the characters of each citizen is also different. There is a rising question whether the points of character education values that have been formulated by the government can be applied in a pluralistic society.

The urgency of character education in Indonesia has been recognized since the beginning by the nation's leaders. This is understood from the expression of Soekarno, the first president, quoted by Samani and Hariyanto, as follows: "This nation must be built by prioritizing character development (character building) because this characteristic building will make Indonesia a nation that is great, advanced, victorious, and dignified. If this character building is not carried out, the Indonesian nation will become a coolie nation" [1].

Thomas Lickona [2], reveals that there are several signs of an era that must be watched out for because they are an indication of a nation heading towards the brink of destruction, namely (1) violence among teenagers is increasing, (2) vocabulary and the language used is increasingly harsh and worsening, (3) peer-group which has a very strong influence in an act of violence, (4) behaviour that causes more damage to a person, such as increased alcohol use, drugs and free sex, (5) increasingly blurred guidelines good and bad morals, (6) decreasing work ethic, (7) lowering respect for parents and teachers, (8) lowering one's responsibility as an individual as well as a citizen, (9) honest character which is increasingly uncultured, and (9) there is a feeling of suspicion or hatred towards others.

The signs of national destruction that were mentioned by Thomas Lickona, seem to have been seen in Indonesia. To mention among them is violence that occurs among adolescents, including brawls between students, which was recorded by the National Commission for Child Protection that there were 355 cases throughout 2013, which shows an increase in Bandung the previous year which was only 147 cases. Of the 355 cases, 30 students died in the brawl, apart from that many were injured (www.tribunnews, com, accessed on 28 October 2018). Not only that, other symptoms of violence have also become increasingly visible, such as the increasing number of motorcycle gangs and leading to acts of violence in the form of persecution, bullying, and even killings that are disturbing the community.

The signs of the destruction of a nation that have been put forward continue to other signs, for example the behaviour of promiscuity (free sex) among students and university students. A survey institute, Sexual Behaviour Survey, conducts surveys in five major cities in Indonesia, namely Jabodetabek, Bandung, Yogyakarta, Surabaya, Semarang. The results were astonishing, of the 663 respondents interviewed, 39\% of respondents who were still teenagers between 15-19 years had had sex. While the remaining $61 \%$ have sex at the age of $30-35$ years [3] 
Another problem that is a sign of the nation's destruction is the rampant corruption cases committed by various government agencies, including the executive, legislative and judiciary, which sometimes collaborate with private parties. Kompas Research and Development in 2012 revealed the fact that during 2004-2011 there were 158 officials (governors, regents and mayors) who committed corruption. Furthermore, in 2008-2011 there were 42 members of the DPR who were caught up in corruption. Not only that, several unscrupulous members of the DPR were also involved in corruption in the election for Senior Deputy Governor of Bank Indonesia. Corruption cases have also involved the KPU, the Judicial Commission, KPPU, the Directorate General of Taxes, Bank Indonesia, and so on.

In addition, the condition of Indonesian society is getting worse, marked by rampant fighting, robbery, murder, injustice, acts of violence, social inequality, sexual harassment, fraud and drug abuse. Likewise, the problem of tolerance is decreasing. This is indicated by cases of burning houses of worship, expelling followers of certain religions or beliefs, as reported by various electronic and printed media.

Seeing these conditions, the government has worked hard to solve cases that have made Indonesia suffer. One of the efforts made is to develop character education, because this is one of the effective drugs to overcome the moral decline of the nation [1]. Character education is simply an education which builds and develops the noble character that is in students by teaching, practicing, making wise decisions based on character values, which are derived from religious values, Pancasila, and the cultural heritage of the Indonesian nation. How does the sharia maqasid view the character education values formulated by the Indonesian government?

\section{A. Research Objective}

Stuying and analyzing the values of character education of 18 points from the perspektive of Maqashid syaria, in order to strengthen its existence to be applied in various aspects of life, not only in schools but also in a pluralstic society.

\section{B. Previous Studies}

There have been many writings, both in the form of books or research on the values of character education, which have been carried out by previous writers. To mention among them is Fatchurrahman [4], with the title: Character Education Development; Ministry of National Education [5], with the title: Development of National Culture and Character Education: School Guidelines; Kesuma et al. [6], with the title: Character Education: Theory and Practice Studies in Schools. Furthermore, Kurniawan [7], with the title: Character Education: Integrated Conception and Implementation in Family, School, College, and Community Environment. Likewise, Muslich [2], with the title: Character Education: Answering Multidimensional Crisis Challenges.

These writings have succeeded well in providing an explanation of character education as a development of the education that has been carried out so far. Even so, none of these writings have attempted to link with maqashid sharia, which is actually important to do considering that aside from the issue of education, the elements of maqashid rules provide an explanation of the importance of religious elements in education. This is what will be tried to see the values of character education as a whole from the aspect of maqashid sharia.

\section{MethodOLOGY}

This study is carried out through library research within the context of investigating the 18 points of character education values that have been formalized by the Government in the implementation of education in various fields, along with the interpretations that have been carried out by education experts, collected through literature studies. It is proven that the character education values that have been formulated are very compatible with Islamic teachings, especially with the maqasid sharia approach, whose essence is to realize the merit of humans, regardless of religion and belief, both in this world and in the hereafter, by maintaining five principles known as al-kulliyat al-Khams, namely: maintaining religion, soul, intellectuality, decency including honor, and preserving property [8]. The analysis is conducted through qualitativedescriptive.

\section{RESULTS AND DISCUSSION}

There are 8 characters of educational values comprising: 1 ) Religious; 2) Honest; 3) Tolerant; 4) Disciplined; 5) Hard working; 6) Creative; 7) Independent; 8) Democratic, 9) Curious; 10) Having national pride; 11) Loving the homeland; 12) Appreciating achievements; 13) Friendly/ communicative, 14) Peace-loving, 15) Passionate on reading; 16) Caring about the environment; 17) Caring about social issues; and 18) Responsible.

To improve the quality of education in various aspects, the Indonesian nation has formulated 18 points of character education values which serve as guidelines and references in the implementation of the teaching and learning process. The intended character values are:

- Religious, namely obedient behavior in carrying out the teachings of the religion he adheres to, having tolerance in various practices of other religions, and establishing harmony with adherents of other religions;

- Honest, namely behavior based on an effort to make himself a person who can be trusted either through words, actions or work by stating what it is, having integrity or being open;

- Tolerant, namely attitudes and actions that respect differences in religion, ethnicity, opinions, attitudes and actions of others who are different from oneself;

- Disciplined, namely actions that show orderly behavior and obey various rules and regulations; 
- Hard working, namely behavior that shows serious efforts in overcoming various obstacles to learning, assignments and completing tasks as well as possible;

- Creative, namely the attitude in thinking and solving problems in a flexible and innovative manner, being brave in making decisions wisely, and willing to listen to other people's opinions so that they can create something new from what they already have;

- Independent, namely attitudes and behaviors that are not easy to depend on others to complete tasks;

- Democratic, namely a way of thinking, behaving, and acting which values one's rights and obligations as others;

- Curious, namely attitudes and actions that always seek to know more deeply and extensively from something that is studied, seen and heard;

- Having national pride, namely a way of thinking, acting and having an insight that places the interests of the nation and the state above the interests of themselves and their groups;

- Loving the homeland, namely ways of thinking, behaving, and acting that show loyalty, concern, and high respect for the nation, the physical, social, cultural, economic and political environment of the nation

- Appreciating achievements, namely attitudes and actions that pushing himself to produce something useful for society, recognizing and respecting the success of others;

- Friendly/communicative, namely actions that show a sense of pleasure to talk, socialize and cooperate with other people;

- Loving peace, namely attitudes, words and actions that cause others to feel comfortable and secure in their presence;

- Passionate about reading, namely the habit of taking time to read various readings that are beneficial to him;

- Caring about the environment, namely attitudes and actions that always strive to prevent damage to the surrounding charitable environment and develop various efforts to repair natural damage that has occurred;

- Caring about the social issues, namely attitudes and actions that always want to provide assistance to other people and communities in need, and

- Responsible, namely the behavior of a person in carrying out his obligations or duties given to him wholeheartedly, able to control himself and be consistent against a choice or decision that has been taken.
The values of character education that have been formulated appear to be very much in accordance with Islamic teachings, especially with the approach or in the perspective of maqasid sharia, whose essence is to realize the merit of humans, regardless of religion and ethnicity, both in this world and in the hereafter, by maintaining the five principles known as al-kulliyat al-Khams, namely: maintaining religion, soul, intellect, descent including honor, and maintaining property. [8].

The aforementioned values provide direction for national development. The points thereof are guidelines in carrying out various activities in various fields in order to prosper the Indonesian people. When these values are interpreted correctly, practiced, guided, they can be used as a compass to realize the merit and happiness of humans, both individually and socially, can maintain kinship systems and relationships or interact with other people, whether of the same religion or of different religions, and can develop character education in Indonesia. In short, by practicing and guiding the values of character education, the development of world civilization in Indonesia can be carried out well.

In Indonesia, neither the government nor the citizens must have anti-religion or atheism; religiousness is an important element. The state guarantees freedom for every citizen to embrace religion and worship according to their beliefs; in the State of Indonesia there is no compulsion in religion. Thus, basically religious values explain that the Indonesian nation and every citizen must acknowledge the existence of God [9].

Maqasid sharia with the principle of the importance of maintaining religion (hifzh ad-din) views religious values in character education as the basis of faith as citizens. According to maqasid sharia, the dimension of faith lies in the qalb of each individual. Therefore, a person is not allowed to force others to believe certain beliefs. This is understood from the verse of the Koran which means: "There is no compulsion in religion, in fact it is clear between the right path and the wrong way ..." (Surah al-Baqarah: 256). In the perspective of maqasid syari'ah, it can be understood that there is no compulsion in adhering to religion, because for those who have knowledge they will immediately know what is true and what is wrong. This verse, therefore, prohibits people from putting pressure on others to follow certain faiths under conditions of compulsion.

As it is known that with the principle of preserving religion, internally maqasid syari'ah means that the substance of sharia is to maintain faith or belief, individual or social worship as an embodiment of Allah's habl min and habl min an-nas, including habl min al-alam. Furthermore, externally, towards parties of different religions and different religious understandings, the above principles also mean that Islam teaches tolerance and is honest in the values of character education in Indonesia.

Furthermore, that humans have high dignity, culture, and are aware of values or norms. This is an essence and an identity, which is why humans are called human dignity. Several values of character education mean that an action or 
decision taken is based on objective norms, not carried out on the basis of subjectivity or arbitrariness (wrongdoing), but full of responsibility. In addition, in an action or decision taken, it must always be based on cultural values, legal norms, decency, social norms, religious norms [10].

Everyone, regardless of race or color, has human potential. Each of them has high dignity, so it must be treated according to the values of character education, in accordance with their nature as a noble creature of God. Whereas every citizen has the same position, has the same obligations and rights [10]. Therefore, every citizen is guaranteed rights and freedom in relation to God, fellow human beings, with the state, with society. Including in this case, guaranteed freedom in expressing opinions and obtaining a decent life in accordance with human rights. This means that a just and civilized humanity for the Indonesian nation originates from the teachings of God Almighty, in accordance with human nature as its creation. Thus, tolerance must be put forward.

Maqasid syariah views that the values of character education include Islamic teachings. Many verses instruct us to be disciplined, work hard and be creative. The principle of maintaining reason in maqasid sharia teaches us to nurture and develop the potential to think and be creative, read diligently for self-righteousness and increase knowledge, and increase the insight needed to build a nation.

Furthermore, with the principle of maintaining offspring and honor, maqasid syari'ah views that humans have the same position, have the same obligations and rights; Then sharia guarantees his basic rights, both to realize and develop his selfactualization and his interactions with God, fellow human beings, friendly and communicative. In the Al-Qur'an it is stated: "And indeed, we have glorified the children of Adam ..." (Surah al-Isra':70). Since humans are noble beings, we should be mutually exclusive respect one another, love peace so as to achieve a life of peace, live peacefully with others. In addition, we should get along well, get along politely in accordance with religious norms and in accordance with good morals. The Prophet once said, which means: "Associate with others with good morals". This is in line with friendly / communicative values in character education values. With morals, we will not slander one another, we will not issue false statements, but we must be honest. With morals, in interacting with other people in society, there will be no envy, disputes and disagreements, so that one can achieve peace of mind and the comfort of life in a pluralistic society. Not only that, with the values of character education, the nation wants to be united, to have a unity of character because of the unity of fate, not to impose equality, namely unity in diversity. The unity of the Indonesian nationality which is formed by the unity of various social backgrounds; culture, politics, religion, ethnicity, and ideology in the territory of Indonesia [11].

In relation to the above, the maqasid syariah views that the values of character education are in accordance with the teachings of universal brotherhood, regardless of skin color, ethnic identity, culture and religion adopted by each. In the Al-
Qur'an it is stated: "All Muslims are brothers" (Surah Yunus: 4). It also states: "and mankind is one people." (SurahalBaqarah: 213). Al-Qur'an is very realistic, that citizens of one country with citizens of another country, will experience meetings and encounters, there will be a multicultural world meeting. Through the encounter of people of different religions, ethnicities, cultures or cultures, citizens of a country, including Indonesia, will get a multi-cultural experience. This kind of experience will be able to lead citizens to introspect and evaluate themselves to take steps forward, creatively to realize the benefit of the Indonesian people.

Furthermore, the values of character education also appear to be very in accordance with maqashid sharia. The value of democracy in it shows the implementation of the verses of the Al-Qur`an in Surah Ash-Sura verse 38, which means: "Their business is being decided by musyawarah between them." Second, the verse of Al-Qur'an in Surah an-Nisa' verse 83, which means: "And when a news comes to them about security or fear, they then broadcast it. If they handed it over to the Apostle and Ulil Amri among them, of course those who want to know the truth (will be able to) know it from them (Rasul and Ulil Amri).

And then, the maqasid sharia views that the values of character education regarding creativity and the national spirit are the most important parts to be implemented to develop the creativity of the Indonesian nation. The existence of a wellplanned order to work hard is clearly part of the maqashid rules, including in improving the economic sector.

In short expression, in the perspective of Maqashid syaria, the 18 points of characters' education can be included inti five categories of substances. Namely (1) the category of maintaining religion: religius, tolerance and honesty; (2) the category of maintaining the soul: peace-loving, national spirit and responsibility; (3) the category of maintaining intellect ( ' $a q l$ ): fond of reading, respect for achievement, curiosity, discipline and independence; (4) caring for the offspring: friendly/communicative, democratic, social care and environmental care; (5) maintaining wealth: Working hard, being creative and being loyal to a country.

\section{CONCLUSION}

The conclusion of the study on the values of character education in Indonesia from the benchmarks of maqasid sharia is that as a whole, it is in line with or not contradicting the five principles or maqasid of sharia. Therefore, the points of character education values formulated by the Government should be supported, be practiced, and be applied in all aspects of the life of Indonesia society, starting from the lowest level to the highest level. Not only in schools but also in a pluralistic society, and the teachers, lecturers and all citizens should support the values of character education.

\section{RECOGNITION OR AWARD}

This study is limited to the study of character education values with the benchmarks of Islamic maqasid. In this study, 
there may appear to be coercion which the author is not aware of, when highlighting it with the principles or rules of maqasid sharia. In connection with this, there are many approaches or benchmarks that can be used in seeing or highlighting the values of character education, apart from what the author has done.

\section{REFERENCES}

[1] M. Samani and M.S. Hariyanto, Konsep dan model pendidikan karakter. Bandung: PT Remaja Rosdakarya, 2011.

[2] M. Muslich, Pendidikan karakter: menjawab tantangan krisis multidimensional. Bumi Aksara, 2011.

[3] A.G.A. Wahid, M.A. Darraz, and A.F. Fanani, Fikih Kebinekaan: Pandangan Islam Indonesia Tentang Umat, Kewargaan, dan Kepemimpinan Non-Muslim. Bandung: Mizan dan Maarif Institue, 2015 .
[4] H.P. Fathurrohman, Pengembangan pendidikan karakter. Reflika Aditama, 2013.

[5] Kemendiknas. Pengembangan Pendidikan Budaya dan Karakter Bangsa: Pedoman Sekolah. Jakarta: Badan Penelitian an Pengembangan Pusat Kurikulum Kemendiknas, 2010.

[6] D. Kesuma, C. Triatna, and J. Permana, Pendidikan Karakter Kajian Teori dan Praktik di Sekolah, Bandung: PT. Remaja Posdakarya, 2011.

[7] S. Kurniawan, Pendidikan Karakter: Konsepsi Dan Implementasinya secara terpadu Dilingkungan Keluarga, sekolah, Perguruan Tinggi. Yogyakarta: Ar-Ruzz Media, 2013.

[8] A.H. Al-Ghazali and M.B. Muhammad, al-Mustashfa min 'ilm al-Usul, Beirut: Dar al-Fikr, pp, 287

[9] R. Daman, Panacasila Dasar Falsafah Negara, Jakarta: Rajawali Press, 1992, pp. 97.

[10] B. Salam, Filsafat Pancasilaisme, Jakarta: Rineka Cipta, 1999, p. 29.

[11] B. Hayat, Mengelola Kemajemukan Umat Beragama. Jakarta: PT. Saadah Pustaka Mandiri, 2015, p. 25. 